\title{
THE SUNDANCE FAULT: A NEWLY RECOGNIZED SHEAR ZONE AT YUCCA MOUNTAIN, NEVADA
}

By R.W. Spengler ${ }^{1}$, C.A. Braun², L.G. Martin², and C.W. Weisenberg ${ }^{2}$

U.S. GEOLOGICAL SURVEY

Open-File Report 94-49

Prepared in cooperation with the U.S. DEPARTMENT OF ENERGY under Interagency Agreement DE-A108-92NV10874

\footnotetext{
${ }^{1}$ U.S. Geological Survey, Denver, CO

2 Scientific Applications International Corporation, Golden, CO
}

Denver, Colorado

1994 


\section{U.S. DEPARTMENT OF THE INTERIOR \\ BRUCE BABBITT, Secretary}

U.S. GEOLOGICAL SURVEY

Robert M. Hirsch, Acting Director

The use of trade, product, industry, or firm names is for descriptive purposes only and does not imply endorsement by the U.S. Government.

For additional information write to:

Chief, Geologic Studies Program Yucca Mountain Project Branch U.S. Geological Survey

Box 25046, MS 421

Denver Federal Center

Denver, CO 80225
Copies of this report can be purchased from:

U.S. Geological Survey

Earth Science Information Center

Open-File Reports Section

Box 25286, MS 517

Denver Federal Center

Denver, CO 80225 


\section{CONTENTS}

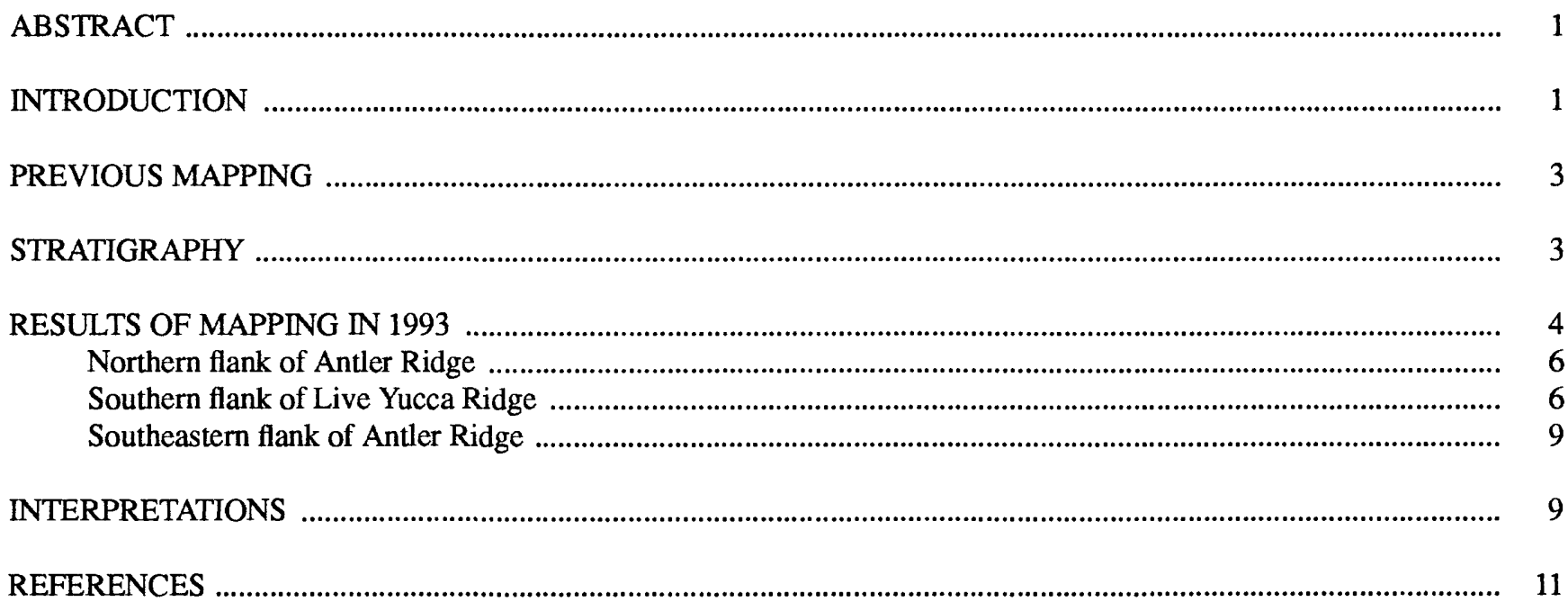

\section{FIGURES}

1. Map of Yucca Mountain showing the distribution of structural features within and surrounding the proposed repository area and the location of study areas along the southern and central parts of the Ghost Dance fault

2. Stratigraphic column showing diagnostic field characteristics of the zones of the Tiva Canyon Tuff (provisional) at Antler Ridge

ap showing generalized geology of the Split Wash area showing offset of lithostratigraphic units

3. Map showing generalized geology of the Split Wash area show
along the Ghost Dance fault system and Sundance fault

4. Map showing generalized geology of the eastern part of Antler Ridge showing offset of lithostratigraphic units along the Sundance fault

5. Map of Yucca Mountain showing the location of the Sundance fault relative to structural features mapped by Scott and Bonk (1984) and location of USW UZ-16 drill hole. 


\title{
THE SUNDANCE FAULT: A NEWLY RECOGNIZED SHEAR ZONE AT YUCCA MOUNTAIN, NEVADA
}

\author{
By R. W. Spengler, C. A. Braun, L. G. Martin, and C. W. Weisenberg
}

\begin{abstract}
Ongoing detailed mapping at a scale of 1:240 of structural features within the potential repository area indicates the presence of several previously unrecognized structural features. Minor north-trending west-side-down faults occur east and west of the Ghost Dance fault and suggest a total width of the Ghost Dance fault system of nearly $366 \mathrm{~m}(1200 \mathrm{ft})$. A zone of nearvertical $\mathrm{N} 30^{\circ}-40^{\circ} \mathrm{W}$-trending faults, at least $274 \mathrm{~m}(900 \mathrm{ft})$ wide, has been identified in the northern part of our study area and may traverse across the proposed repository area. On the basis of a preliminary analysis of available data, we propose to name this zone the "Sundance fault system" and the dominant structure, occurring near the middle of the zone, the "Sundance fault". Some field relations suggest left-stepping deflections of north-trending faults along a pre-existing northwest-trending structural fabric. Other field observations suggest that the "Sundance fault system" offsets the Ghost Dance fault system in an apparent right lateral sense by at least $52 \mathrm{~m}$ $(170 \mathrm{ft})$. Additional detailed field studies, however, are needed to better understand structural complexities at Yucca Mountain.
\end{abstract}

\section{INTRODUCTION}

Yucca Mountain consists of a series of north-trending, east-tilted, 1- to 4-km (0.6 to 2.5mi)-wide structural blocks. These blocks are bounded by north-trending westward-dipping highangle fault zones that displace volcanic strata of Tertiary age by $100 \mathrm{~m}(328 \mathrm{ft})$, and locally by as much as $400 \mathrm{~m}$ (1312 ft; Scott and Bonk, 1984). The potential area for long-term storage of highlevel nuclear waste is situated within the central block of Yucca Mountain, which is bounded on the west by the Solitario Canyon fault zone and on the east and southeast by numerous closely spaced northwest- and northeast-trending faults (fig. 1). From north to south, we divide the central block into three distinctive structural domains on the basis of fault intensity and orientation, topography, and attitude of volcanic strata. Strata in the northern structural domain dip $5^{\circ}$ to $10^{\circ}$ southeastward and are cut by a series of linear northwest-trending washes, most of which are underlain by, or coincident with, zones of right-lateral strike-slip faulting (Scott and Bonk, 1984). The southernmost strike-slip fault is suspected to underlie Drill Hole Wash, directly north of the northeastern margin of the potential repository area (fig. 1; Scott and others, 1984). In large part, the potential repository area encompasses the central structural domain, where strata commonly dip eastward from $6^{\circ}$ to $9^{\circ}$ and are dominantly cut by east-trending washes. Here, the Ghost Dance fault is considered the dominant structural feature, as it is the only through-going fault that offsets the exposed 12.5-m.y.-old Tiva Canyon Member of the Paintbrush Tuff. It has recently been proposed to elevate the Tiva Canyon Member to Formation status (D. A. Sawyer and others, written communications, Feb. 10, 1993), and therefore, we will provisionally refer to it as the Tiva Canyon Tuff. The southern domain is characterized by an abundance of closely spaced northwesttrending and ancillary northeast-trending faults with vertical separations on the order of several meters. As mapped by Scott and Bonk (1984), some discontinuously exposed northwest-trending 


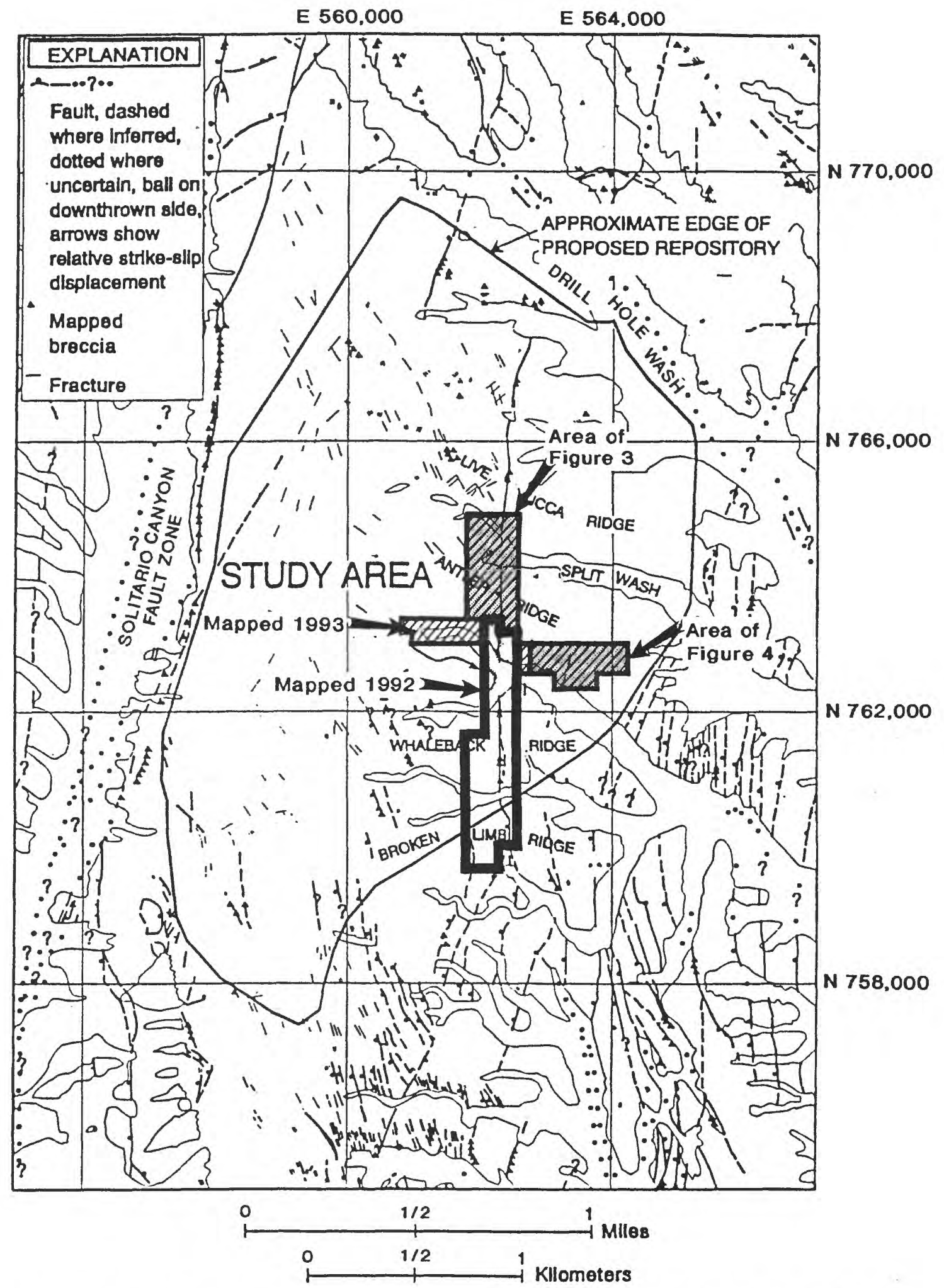

Figure 1.-- Map of Yucca Mountain showing the distribution of structural features within and surrounding the proposed repository area and the location of study areas along the southern and ceniral paris of the Ghost Dance fault (structural features from Scott and Bonk, 1984). Nevada State Coordinates are shown in feet. 
faults extend northward well into the proposed repository but details of their character have not been studied (fig. 1). This paper summarizes salient structural features that have been identified from detailed field mapping of parts of the central structural domain.

\section{ACKNOWLEDGMENTS}

We thank D. C. Buesch of the U. S. Geological Survey and R. P. Dickerson of Science Applications International Corporation for providing thoughtful and constructive technical reviews of the paper.

\section{PREVIOUS MAPPING}

In 1992, we initiated a project to map fractures and other observable structural features such as zones of brecciation and separations of lithostratigraphic units on either side of the surface trace of the Ghost Dance fault (Spengler and others, 1993). We first established an internal grid system, composed of $61 \mathrm{~m}$ by $61 \mathrm{~m}(200 \mathrm{ft}$ by $200 \mathrm{ft})$ areas within the framework of the Nevada State Coordinate System. Field mapping was done at a scale of 1:240 and subsequently compiled at a scale of 1:600 (Spengler and others, 1993). The mapped area straddles the surface trace of the Ghost Dance fault, bounded on the north by Antler Ridge and on the south by Broken Limb Ridge

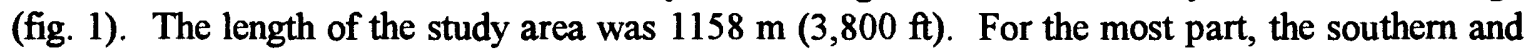
northern halves of the study area were, respectively, $244 \mathrm{~m}(800 \mathrm{ft})$ and $183 \mathrm{~m}(600 \mathrm{ft})$ in width (fig. 1). Based on detailed mapping in 1992 (fig. 1), we found that the Ghost Dance fault is the dominant fault in a previously unrecognized structural system, composed of minor north-trending faults and near-horizontal lithostratigraphic units that extend over a width of at least $213 \mathrm{~m} \mathrm{(700}$ $\mathrm{ft}$ ). This structural system, referred to as the Ghost Dance fault system, was also found to exhibit a preferential north- to northwest-trending fracture orientation with isolated occurrences of northto northwest-trending breccia (Spengler and others, 1993). The thickest and most intensely crushed breccia is found along the Ghost Dance fault. The character of this breccia and the significantly larger vertical separation of lithostratigraphic units are key features that are currently used to distinguish the Ghost Dance fault from other north-trending faults within the system.

\section{STRATIGRAPHY}

The uppermost 60 to $75 \mathrm{~m}$ (200 to $250 \mathrm{ft}$ ) of moderately to densely welded zones of the Tiva Canyon Tuff are moderately to poorly exposed along steep-sided east- to southeast-trending drainages. Some localities are almost completely covered with thick talus deposits. Lithostratigraphic units of the Tiva Canyon Tuff, as originally described by Scott and Bonk (1984), are based on the macroscopic variations in groundmass devitrification, degree of welding, shape of eroded slopes, texture of weathered surfaces, lithophysal cavity abundance, lithic fragment abundance, and phenocryst abundances. These units, which include, from bottom to top, the hackly, lower lithophysal, clinkstone, upper lithophysal, and upper cliff, and locally, the upper vitrophyre, provide the detailed lithostratigraphic framework for the recognition of vertical separations on the order of a few meters at a scale of 1:12000 (Scott and Bonk, 1984).

During our detailed mapping in 1992, we increased the number of criteria for recognizing subtle contacts between units of the Tiva Canyon Tuff. These criteria include roughness coefficients of freshly broken surfaces (Barton and Choubey, 1977), working hardness (Hunt, 1984), size and shape of lithophysal cavities, orientation and abundance of foliated pumice clasts, and initial appearance of diagnostic lithic fragments and accessory minerals such as bronze-colored 
biotite. Our systematic development and use of multiple criteria for each contact between units, currently allow us to recognize apparent offsets of less than a meter (fig. 2).

\section{RESULTS OF MAPPING IN 1993}

In 1993, we extended our detailed mapping north, east, and west of the our previously mapped area to include an additional 70 areas. As in previous mapping each area measures $61 \mathrm{~m}$ by $61 \mathrm{~m}(200 \mathrm{ft}$ by $200 \mathrm{ft})$. Our 1993 mapping extended approximately $549 \mathrm{~m}(1800 \mathrm{ft})$ northward along the Ghost Dance fault to include the northern flank of Antler ridge and southern flank of Live Yucca Ridge. Two east-west strip maps were also completed. The two strip maps, for the most part, are $122 \mathrm{~m}$ (400 ft) wide, extending to distances of $549 \mathrm{~m}(1800 \mathrm{ft})$ east and 366 $\mathrm{m}$ (1200 ft) west of the mapping completed in 1992 along the southern flank of Antler Ridge (fig. 1). The primary objective for mapping the strips was to establish the full width of the area where north-trending faults could be detected along the Ghost Dance fault system.

Our detailed mapping indicates that the width of the area, containing as many as six

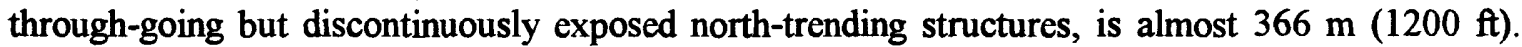
This width appears relatively uniform from Broken Limb Ridge northward to at least the south side of Antler Ridge; a distance of about $1 \mathrm{~km}(0.6 \mathrm{mi})$. The Ghost Dance fault, which maintains a position near the middle of the system, remains the dominant structural feature. Almost all ancillary north-trending faults indicate west-side-down offsets that commonly range between $3 \mathrm{~m}$ and $6 \mathrm{~m} \mathrm{(10} \mathrm{ft} \mathrm{and} 20 \mathrm{ft})$. From Broken Limb Ridge to Live Yucca Ridge, ancillary faults maintain a fairly uniform map spacing from the Ghost Dance fault of 114 to $198 \mathrm{~m} \mathrm{(375} \mathrm{to} 650 \mathrm{ft}$ ) for the West Hinge fault, 30 to $76 \mathrm{~m}$ (100 to $250 \mathrm{ft}$ ) for the West fault, and 24 to $69 \mathrm{~m}$ (80 to 225 $\mathrm{ft}$ ) for the East fault. Within the structural system dips of lithostratigraphic units are commonly less than $4^{\circ}$.

The width of the Ghost Dance fault system is consistent with the width of the area where north- to northeast- trending faults had been previously mapped on either side of the Ghost Dance fault by Scott and Bonk (1984). These ancillary faults were previously interpreted to have northern terminations near the crest of Broken Limb Ridge at the southeastern margin of the proposed repository area (fig. 1; Scott and Bonk, 1984). In contrast to mapping at a scale of 1:12000, our mapping indicates that these faults extend northward well into the proposed repository area.

Northward progression of our structural mapping has led to the recognition of numerous northwest and northeast trending structures north of Whale Back Ridge (fig. 1). Most of these structures indicate apparent offsets of lithostratigraphic units of the Tiva Canyon Tuff by only a few meters. However, geometrical relations of many diffusely spaced northeast- and northwesttrending faults are incompletely understood.

A conspicuous variation in structural style appears to occur north of Antler Ridge and along the southeastern flank of Antler Ridge, which suggests the existence of a previously unrecognized shear zone. The existence and character of this shear zone are based on the appearance of the following structural complexities: 1) abrupt increase in northeastward dip of foliation in lithostratigraphic units, 2) closely spaced northwest-trending shears with apparent right lateral separation, 3) intensely brecciated rock in close proximity to northwest-trending fractures, 4) abrupt decrease in vertical separation along the Ghost Dance fault, and 5) apparent right lateral offset of the Ghost Dance fault system. These field observations have been documented at three critical but isolated exposures along the northern flank of Antler Ridge, along southern flank of Live Yucca Ridge, and along the southeastern flank of Antler Ridge (fig. 1, 3, 4). 


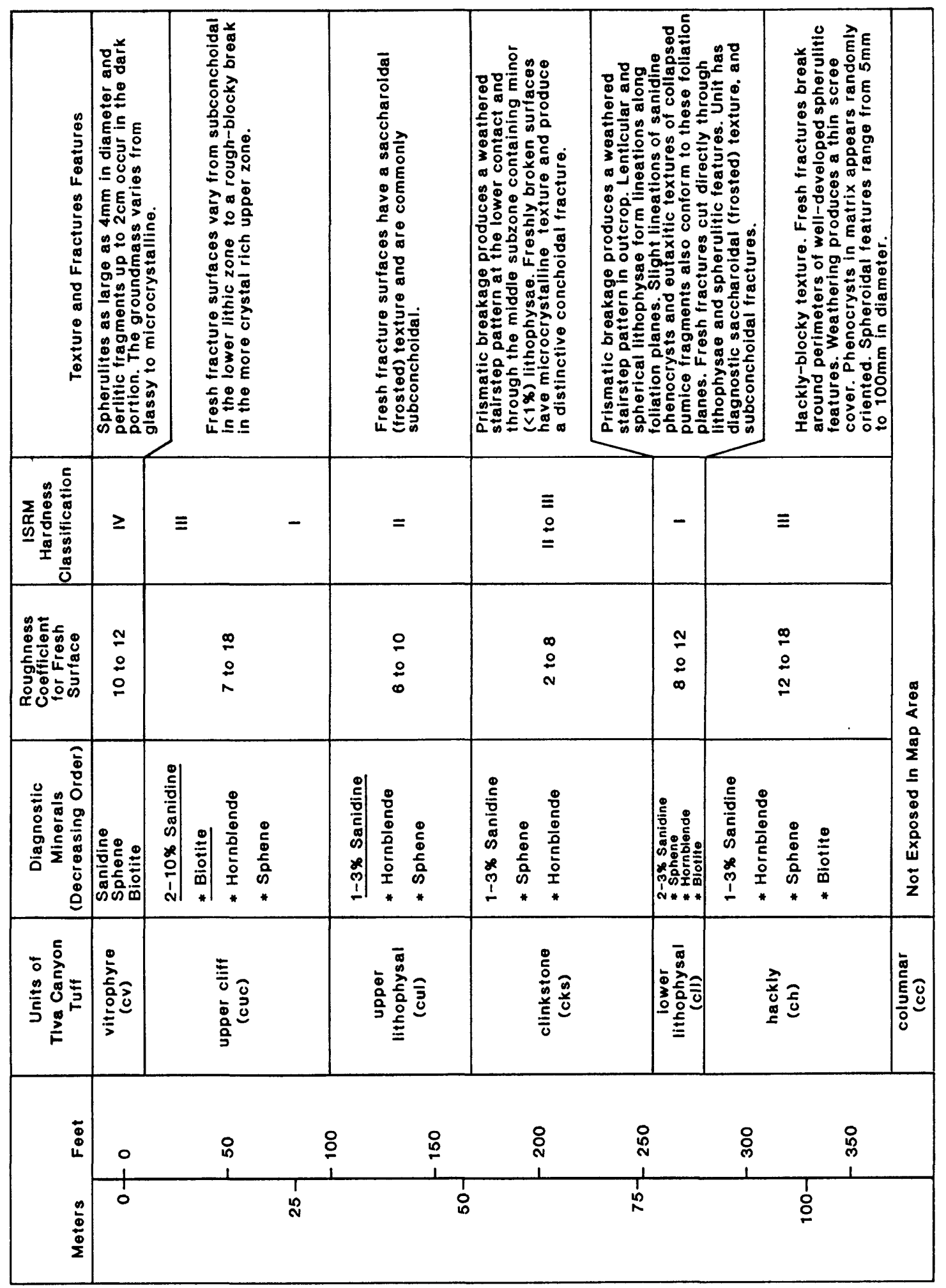

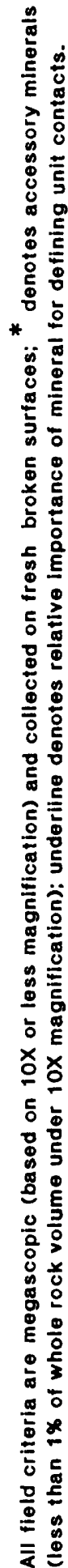

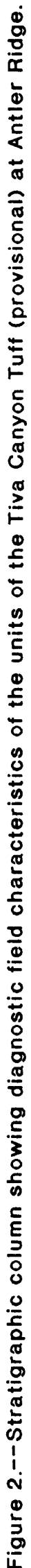


Mapping of a 244-m (800-ft)-wide area from the southern flank to the northern flank of Antler Ridge reveals a gradual increase in structural complexity (fig. 3). Small-scale northwestand northeast-trending faults increase in abundance. For the most part, the north-trending faults are traceable northward, maintaining a similar horizontal spacing and vertical separation as mapped to the south. From the south side of Antler Ridge to the north side of Antler Ridge, a distance of about $168 \mathrm{~m}(550 \mathrm{ft})$, vertical separation of lithostratigraphic units along the Ghost Dance fault is relatively uniform, varying from 15 to $12 \mathrm{~m} \mathrm{(50} \mathrm{to} 40 \mathrm{ft})$. However, the high-angle Ghost Dance fault is offset in an apparent right lateral sense by about $15 \mathrm{~m}(50 \mathrm{ft})$ along an inferred northwest-trending shear (fig. 3).

\section{Southern Flank of Live Yucca Ridge}

North of Split Wash a conspicuous and abrupt change in structural style occurs. Along the south-facing slope of Live Yucca Ridge (fig. 1, 3), we have mapped numerous parallel N30 $0^{\circ}$ $40^{\circ} \mathrm{W}$-striking structures, many of which are spaced 5 to $10 \mathrm{~m}$ (16 and $33 \mathrm{ft}$ ) apart and commonly show less than a few meters of right (or) east-side-down separation of lithostratigraphic contacts. Simple geometric considerations suggest that right slip on northwest-trending faults in an area of gentle eastward dips should result in left separation of contacts along south-facing slopes, which are steeper than the dips. The right separation seen along Live Yucca Ridge (and at some places to the south) may be due to local variations in attitudes of lithostratigraphic units and (or) by a vertical component of slip. Within the Ghost Dance fault system, where lithostratigraphic units are nearly horizontal, near-horizontal fault slip can produce variable outcrop patterns depending on local variations in slip line, attitudes of lithostratigraphic units and topography. Alternatively, some offsets, mapped in poorly exposed areas, may be related to slope movements or zonal variations within the Tiva Canyon Tuff.

The West Hinge, Ghost Dance, and East faults maintain a similar relative horizontal spacing on Live Yucca Ridge as seen to the south. The spacing between the West fault and Ghost Dance fault decreases slightly north of Split Wash. Some of the north-trending structures along Live Yucca Ridge appear to break into left-stepping segments connected by short northwesttrending breccia zones. These deflections from a northerly strike may be due to preexisting northwest-trending structures. However, the locations of identifiable north-trending faults within the Ghost Dance fault system along Live Yucca Ridge suggest an apparent right lateral offset of

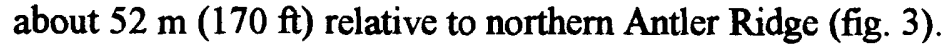

The Ghost Dance fault shows a significant decrease in the amount of vertical separation of

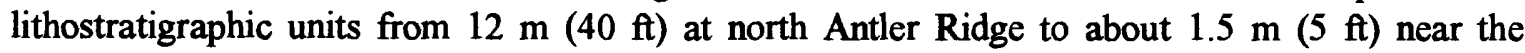
middle of the south slope of Live Yucca Ridge, which corresponds to a map distance of about 305 $\mathrm{m}(1000 \mathrm{ft})$. North of Split Wash, the fault directly east of the Ghost Dance fault that is provisionally referred to as the East fault(?) shows the largest vertical separation of about $3 \mathrm{~m}$ (10 $\mathrm{ft}$ ). If the Ghost Dance fault has been misidentified and is this easternmost fault within our mapped area, a larger amount of right separation can be inferred.

A set of the high-angle $\mathrm{N} 30^{\circ} \mathrm{W}$ fractures, dipping $85^{\circ}$ to $90^{\circ}$ to the southwest, is well exposed at drainage level along Split Wash and extends northwestward for several tens of meters

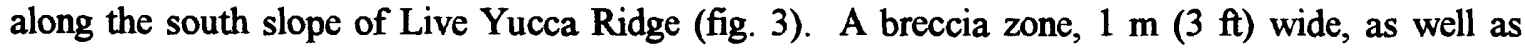
slickensides with a rake of about $2^{\circ}$ to the northwest were also found at this exposure. Some fracture surfaces display subtle mullion structures, suggesting a smoother fracture surface in a near-horizontal direction. Internal layering within the clinkstone unit is well developed at this 


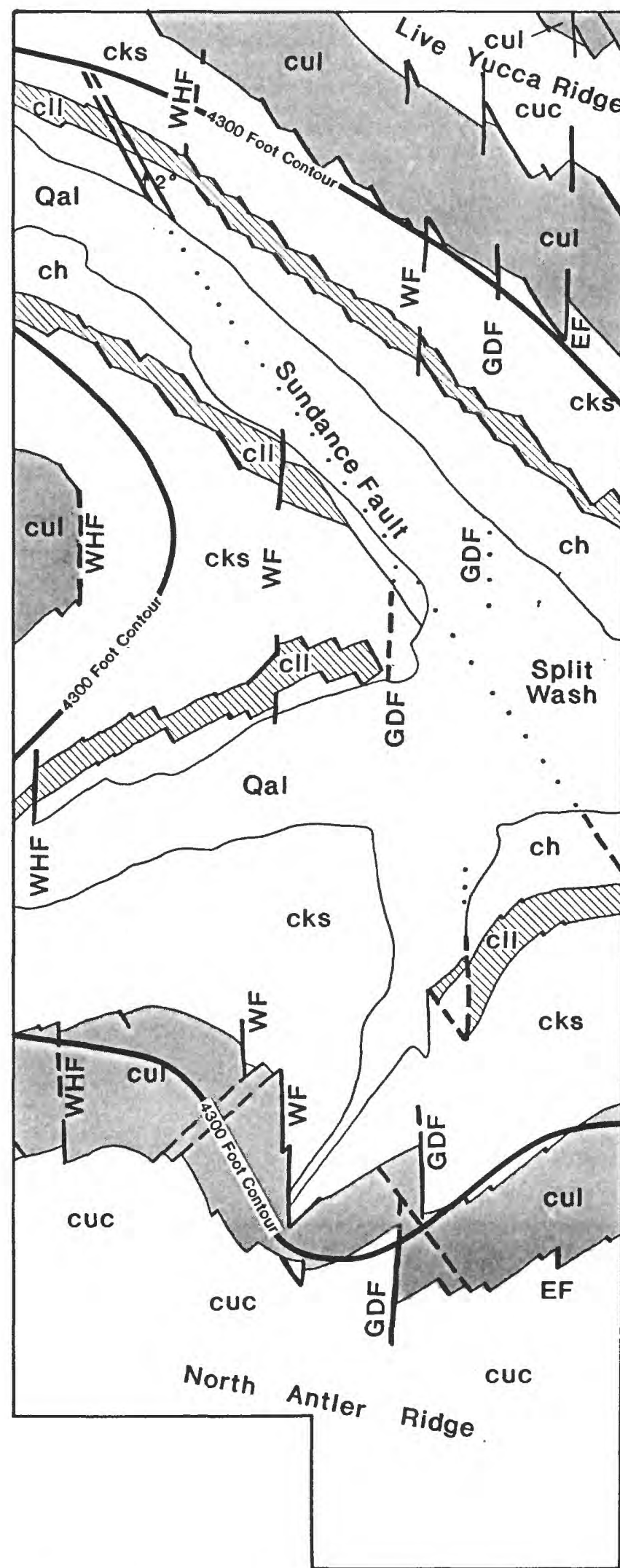

EXPLANATION

UNITS OF TIVA

CANYON TUFF

Qal alluvium

cuc upper cliff

cul upper lithophysal

cks clinkstone

cll lower lithophysal

ch hackly

- Contact

$2^{\circ}$ Fault, dashed where

inferred; dotted

where concealed;

arrow indicates rake of slickensides

WHF West Hinge fault

WF West fault

GDF Ghost Dance fault

EF East fault
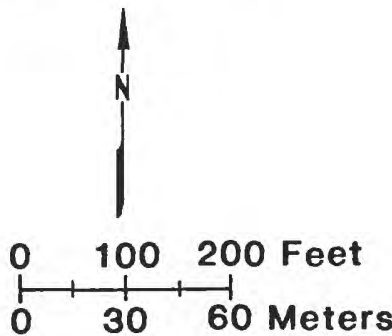

Mapped during 1993 at a scale of 1 inch equals 20 feet

Figure 3.--Generalized geologic map of the Split Wash area showing offset of lithostratigraphic units along the Ghost Dance fault and Sundance fault systems. 


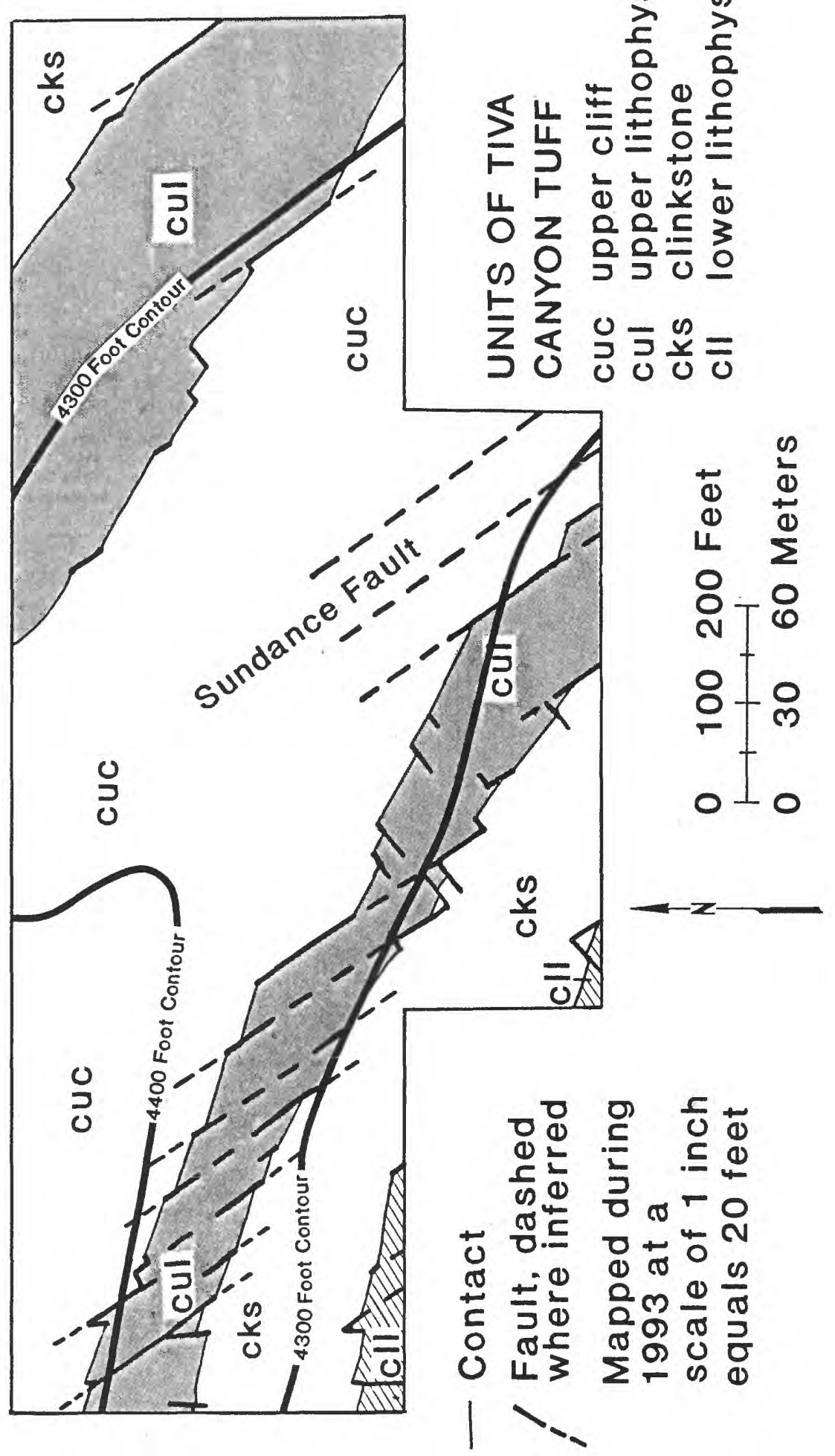

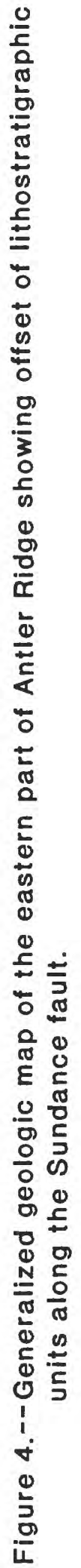


locality, appears horizontal on the west side of the fault, dips gently eastward on the east side of the fault, but shows no recognizable vertical separation. As discussed, the inability to detect any vertical separation may be a combination of nearly vertical faults, nearly horizontal lithostratigraphic units, and horizontal slip. The fracture set can be traced northwestward across Live Yucca Ridge as a lineament on aerial photographs, where it appears to project into area of intense brecciation and into a northwest-trending lineament, depicted on Scott and Bonk (1984; fig. 1). Inferred from available preliminary data, we believe that this structure is the most conspicuous through-going feature near the middle of the shear zone and refer to it as the "Sundance fault".

\section{Southeastern flank of Antler Ridge}

The uppermost part of the upper cliff unit of the Tiva Canyon Tuff commonly forms a ridge-capping cliff several meters thick over much of Yucca Mountain. This cliff is conspicuously absent along the ridge crest of Antler Ridge directly northwest of drill hole USW UZ-16. Close examination of exposures of the upper cliff unit indicate that it is about $14 \mathrm{~m} \mathrm{(45} \mathrm{ft}$ ) thick to the west and about $23 \mathrm{~m} \mathrm{(75} \mathrm{ft)} \mathrm{thick} \mathrm{to} \mathrm{the} \mathrm{east} \mathrm{of} \mathrm{this} \mathrm{geomorphic} \mathrm{feature.} \mathrm{Measurement} \mathrm{of} \mathrm{foliation}$ attitudes in the upper cliff unit along the crest of Antler Ridge indicates an attitude of about N20 W $3^{\circ} \mathrm{NE}$ directly below this geomorphic feature, which increases to about $\mathrm{N} 40^{\circ} \mathrm{W} 15^{\circ} \mathrm{NE}$ east of the feature. Mapping along the south-facing slope of Antler Ridge directly below the geomorphic anomaly indicates the presence of multiple apparent right separations of the contact between the upper cliff and the upper lithophysal units (fig. 4). Although this locality is poorly exposed and no discrete fault planes are observable, more than ten apparent right separations of contacts, commonly spaced 15 to $20 \mathrm{~m}$ (49 to $66 \mathrm{ft}$ ) apart, have been documented within a zone that is at least 274-m (900-ft) wide and trends in a $\mathrm{N} 30^{\circ}-40^{\circ} \mathrm{W}$ direction. These apparent right lateral separations in an area of anomalous northeasterly dips of foliation are consistent with right lateral offsets and suggest an apparent cumulative right separation of as much as $107 \mathrm{~m}$ (350 ft; fig. 4). Alternatively, map patterns may suggest anomalous down-to-the-east displacements. On the basis of reconnaissance mapping, this structurally disrupted zone has been traced southeastward to the base of exposures at Antler Ridge. In the area directly south of drill hole USW UZ-16 numerous northwest-trending structures and (or) conspicuous lineaments have been mapped by Scott and Bonk (1984; fig.5).

\section{INTERPRETATIONS}

The Ghost Dance fault is the dominant fault in a structural system composed of minor north-trending west-side-down steeply dipping faults that extends over a width of nearly $366 \mathrm{~m}$ (1200 ft). Northward extension of our mapping at a scale of 1:240 reveals localities where closely spaced northwest-trending fractures, northwest-trending separations of lithostratigraphic units, near-horizontal slickensides, subtle mullion structures, and northwest-trending breccia appear to dominate the structural style. Preliminary analysis of the eastward extension of our mapping suggests the presence of a northwest-trending zone that shows either anomalous right lateral or anomalous east-side-down displacements, an abrupt increase in dip of foliation, and abrupt variation in the erosional thickness of the upper cliff zone. These relationships occur within a northwest-trending structural zone that is at least $274 \mathrm{~m}(900 \mathrm{ft})$ wide and is herein referred to as the "Sundance fault system". We propose to name the most conspicuous through-going structure, located near the middle of the system, the "Sundance fault" (fig 5). The "Sundance fault system" documents the presence of northwest-trending strike-slip structural features within the central structural domain of the central block. On the basis of structural lineaments and concentrations of 


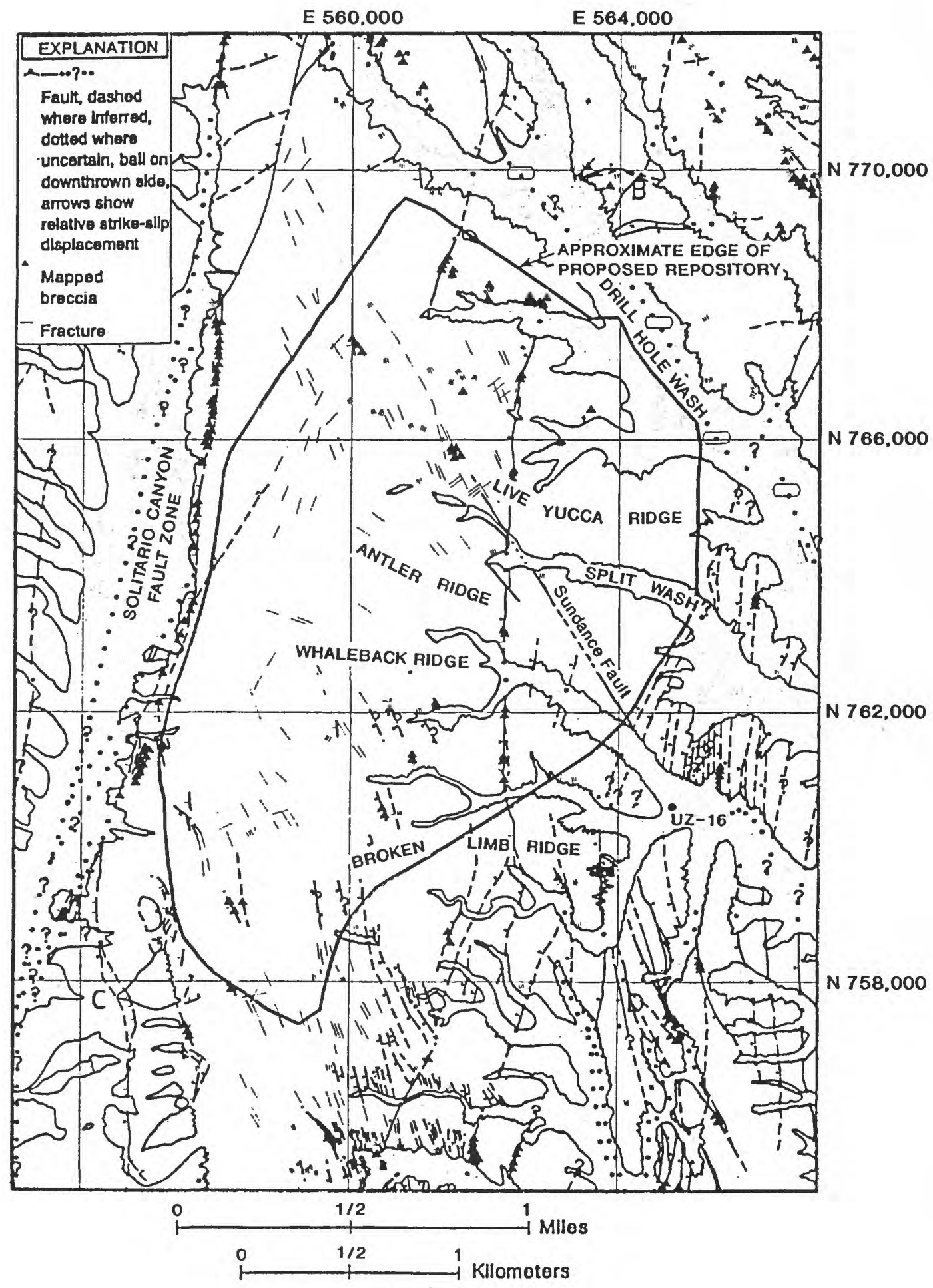

Figure 5.-- Map of Yucca Mountain showing the location of the Sundance Fault relative to structural features mapped by Scott and Bonk (1984), and Iocation of USW UZ-16 drill hole. 
brecciated rock (initially identified by Scott and Bonk (1984); fig. 5), our detailed mapping, and reconnaissance observations made outside of our mapped area, this zone appears to extend northwestward across the potential repository area. To the southeast, the Sundance fault system appears to project into a conspicuous set of northwest-trending faults that occurs directly southeast of the southeastern margin of the potential repository area (fig. 5). If these previously mapped structural features are the northwestern and southeastern extensions of this same northwesttrending system, it may extend over a distance of at least $3 \mathrm{~km}$ (1.9 mi, fig. 5).

Geometric relations between attitudes of lithostratigraphic units, fault slips, and topography have resulted in map patterns that are incompletely understood. Relative age relations between the "Sundance fault system" and the Ghost Dance fault system also remain unresolved. Some field relations suggest that the strike of the north-trending fault system was locally influenced by a pre-existing northwest structural fabric. Other field observations suggest that steeply dipping faults of the Ghost Dance fault system may be displaced in an apparent right lateral sense by at least $52 \mathrm{~m}(170 \mathrm{ft})$.

Additional detailed mapping, particularly along east-west trending profiles, in concert with reconnaissance mapping along inferred northwest and southeast extensions will significantly help clarify map patterns, relative age relationships of fault systems, and terminations of the "Sundance fault system".

\section{REFERENCES CITED}

BARTON, N. R., and CHOUBEY, V., 1977, The shear strength of rock joints in theory and practice, Rock Mechanics, v. 10, p. 1-54.

HUNT, R. E., 1984, Geotechnical engineering investigation manual, McGraw Hill Book Company, New York.

SCOTT, R. B., BATH, G. D., FLANIGAN, V. J., HOOVER, D. B., ROSENBAUM, J. G., , and SPENGLER, R. W., 1984, Geological and geophysical evidence of structures in northwesttrending washes, Yucca Mountain, southern Nevada, and their possible significance to a nuclear waste repository in the unsaturated zone: U.S. Geological Survey Open-File Report 84-567, 23 p.

SCOTT, R. B., and BONK, JERRY, 1984, Preliminary geologic map of Yucca Mountain, Nye County, Nevada, with geologic cross sections: U.S. Geological Survey Open-File Report 84-494, scale 1:12000.

SPENGLER, R. W., BRAUN, C. A., LINDEN, R. M., MARTIN, L. G., ROSS-BROWN, D. M., and BLACKBURN, R. L., 1993, Structural character of the Ghost Dance fault, Yucca Mountain, Nevada: in High Level Radioactive waste Management, Proceedings of the Fourth International conference, American Nuclear Society, v. 1, pp. 653-659. 